\title{
PATHOLOGICAL STUDIES ON THE EFFECT OF YEAST ON MYCOTOXICOSIS IN RATS
}

\author{
ABEER HASHEM MOSTAFA ${ }^{1}$; ALLAM A. NAFADY ${ }^{2}$; SALAH M. AFIFI ${ }^{2}$; ABDEL-NASER A. \\ ZOHRI $^{3}$; NEVEN ABD EL GHANI ${ }^{1}$ \\ ${ }^{1}$ Pathology Department, Animal Health Institute \\ ${ }^{2}$ Pathology Department, Faculty of Veterinary Medicine, Assiut University \\ ${ }^{3}$ Botany Department, Faculty of Science, Assiut University
}

Received: 16 March 2017; $\quad$ Accepted: 30 April 2017

\begin{abstract}
The present study aimed to investigate the protective effect of yeast against mycotoxicosis induced by Aspergillus parasiticus and Fusarium tricinctum as common fungal contaminants on albino rats. 60 albino rats were randomly divided into three experimental groups: (A, B and C), each contain 20 animals. Group A: rats were kept as a control group was feed on uncontaminated feed and drinking water without any treatments. Group B: animals were feed contaminated diet with aflatoxins in level of $0.5 \mathrm{mg} / \mathrm{kg}$ ration and diacetoxyscirpenol in level of $10 \mathrm{mg} / \mathrm{kg}$ ration. Group C: animals were feed contaminated diet as in group B. mixed with Saccharomyces cerevisiae ( $2 \mathrm{~g} / \mathrm{kg}$ of feed) during the whole time of the experiment. At the end of $1^{\text {st }}, 2^{\text {nd }}, 3^{\text {rd }}$, and $4^{\text {th }}$ month, respectively, five animals from each group were weighted and dissected. Tissue samples were obtained from liver, kidneys and intestine for histopathological examination by light and electron microscope. The rats showed reduction of body weight and weight gain in group B. Addition of yeast to contaminated diet in the group $\mathrm{C}$ improved this reduction. Histopathological and ultrastructural studies revealed pathological changes in liver and kidney in group B. administration of yeast improve the intensity and the prevalence of the lesions and enhances the immune response of the body against mycotoxicosis (Lymphocytes and plasma cells).
\end{abstract}

Key words: Pathological, Yeast, Mycotoxicosis, Rats.

\section{INTRODUCTION}

Mycotoxin contaminated feedstuffs considered a permanent challenge in animal nutrition as health and performance of the animals may be compromised. Several studies have shown that improperly stored feeds can have high levels of aflatoxins while other mycotoxins such as trichothecenes develop in the growing crop due to its being susceptible to certain plant pathogenic fungi like fungi of genus Fusarium (Jouany, 2007). Such combined intake of mycotoxins would lead to a possible higher risk than the intake of one of these mycotoxins alone, numerous researchers have reported that mycotoxins act synergistically combined (Speijers and Speijers, 2004).

Corresponding author: Dr. ABEER HASHEM MOSTAFA

E-mail address: abeerhashim elhendy@yahoo.com

Present address: Pathology Department, Animal Health Institute
Aflatoxins (AF) are metabolites synthesized by the fungi Aspergillus flavus and Aspergillus parasiticus and are classified in to several types. The common four types of $\mathrm{AF}$ are namely $\mathrm{AFB} 1, \mathrm{AFB}_{2}, \mathrm{AFG}_{1}$ and $\mathrm{AFG}_{2}$ (Betina, 1989; Dorner, 2008). Aflatoxins are known to have strong hepatotoxic, carcinogenic and immuno suppressive effects and are regulated by feed/food law in at least 100 countries (van Egmond and Jonker, 2004).

Fusarium mycotoxins are also widely distributed some with carcinogenic properties and others of well-defined toxicology for farm livestock. Fusarium toxins, especially trichothecenes, are more likely to affect livestock (Girish and Smith, 2008). Trichothecenes include T-2, HT-2, diacetoxyscipernol (DAS) and deoxynivalenol (DON or vomitoxin) are of major concern in terms of their ubiquitous distribution and effects on animal health (Placinta et al., 1999). 
Prevention of feed and feedstuffs from possible mold growth and mycotoxins contamination is essential. When contamination cannot be prevented, decontamination of mycotoxins is needed before using these materials. Practical and cost-effective methods for detoxification of mycotoxin-containing feed and feedstuffs are in great demand (Basmacioglu et al., 2005). One of the most recent approaches to the problem has been the use of feed additives to prevent absorption and toxic effects from mycotoxins in farm animals (Moslehi-Jenabian et al., 2010). Baker yeast (Saccharomyces cerevisiae) is one of most important microorganisms in food fermentation, have been shown to bind different mycotoxins strongly to cell wall components (Yildiz et al., 2004). This mode of mycotoxin decontamination is highly promising, although the field is still in its infancy.

Accordingly, this study is designed to investigate the protective effect of yeast against mycotoxicosis developed by Aspergillus parasiticus (aflatoxin producer) and Fusarium tricinctum (Diacetoxyscirpenol, DAS producer) as common fungal contaminants on albino rats.

\section{MATERIALS AND METHODS}

\section{1 - Animals}

Sixty male and female albino rats, of 6-8 weeks old and weighed 135-150g, were obtained from the Faculty of Medicine, Assiut University. Animals were kept in natural environmental laboratory conditions, fed commercial pellet rat feed and water were available ad libitum.

\section{2 - Fungal isolates:}

Two toxigenic fungal isolates Aspergillus parasiticus a highly producer of aflatoxins $\left(\mathrm{B}_{1}, \mathrm{~B}_{2}\right.$, $\mathrm{G}_{1}$ and $\mathrm{G}_{2}$ ) and Fusarium tricinctum a highly producer of diacetoxyscirpenol provided by Botany Dept., Faculty of Science Assiut University.

\section{3 - Yeast culture:}

The Saccharomyces cerevisiae (SC) was obtained as baker dry yeast (Parisienne-Italy) was applied at rate of $2 \mathrm{~g} \mathrm{SC} / \mathrm{kg}$ of feed equivalent (Yildiz et al., 2004). The fungal materials were incorporated into the mixed feed before $\mathrm{SC}$ will be added

\section{4- Preparation of fungal materials: a- preparation of aflatoxin}

Aflatoxin was produced via fermentation of rice by the method of Shotwell et al. (1966) with minor modifications by Oguz (1997). By inoculation with spore suspension of Aspergillus parasiticus and the flasks were incubated at $28^{\circ} \mathrm{C}$ for 15 days. On the fifteenth day, moldy rice was dried and the aflatoxin content was estimated by the thin layer chromatography (Romer, 1975).

\section{b- Preparation of diacetoxyscirpenol}

Diacetoxyscirpenol was prepared as previously described by (Shotwell, 1966) on rice. Briefly, (300 g) broken rice was placed in 1000-ml Erlenmeyer flasks and inoculated with spore suspension of Fusarium tricinctum. The flasks were incubated at $28^{\circ} \mathrm{C}$ for 15 days, then at $15^{\circ} \mathrm{C}$ for another 10 days. On the $25^{\text {th }}$ day moldy rice was dried and the diacetoxyscirpenol content was estimated using thin layer chromatography (TLC) (Gimeno, 1979).

\section{5 - Experimental diet:}

A commercial pellet rat feed with $(16 \%$ crude protein; $2.87 \%$ crude fat; $3.35 \%$ crude fiber and metabolized energy $2700 \mathrm{~kg}$ calorie) was used for control rat as a basal diet. And a known amounts of moldy dried rice cultures containing AF and DAS were incorporated into the basal diet of rat feed to yield $0.5 \mathrm{ppm} \mathrm{AF}+10 \mathrm{ppm}$ DAS and mixed thoroughly before given to animals.

\section{Experimental designs}

60 albino rats were weighted and equally divided into three groups (A, B, and C) each contain 20 animals. The animals of each group were assigned to one of the three dietary treatments in a randomized design for 120 days:

Group A: Rats were kept in parallel as a control and received only uncontaminated feed and drinking water without any treatments.

Group B: Rats received contaminated diet with aflatoxins $\left(\mathrm{B}_{1}, \mathrm{~B}_{2}, \mathrm{G}_{1}, \mathrm{G}_{2}\right)$ in level of $0.5 \mathrm{mg} / \mathrm{kg}$ ration and diacetoxyscirpenol in level of $10 \mathrm{mg} / \mathrm{kg}$ ration.

Group C: Rats received contaminated diet with fungal materials as in group B. mixed with Saccharomyces cerevisiae ( $2 \mathrm{~g} / \mathrm{kg}$ of feed) during the whole time of experiment.

\section{Methods:}

\section{A - Clinical signs and body weight}

Clinical manifestations were recorded during treatment periods and animal's body weights were 
registered along the experimental period before scarification at the end of each treatment protocol.

\section{C - Light and Electron microscopy}

According to the protocol of experiment 5 rats were dissected from each group after $1^{\text {st }}, 2^{\text {nd }}, 3^{\text {rd }}$ and $4^{\text {th }}$ months from the beginning of the experiment. After gross examination, tissue samples were obtained from liver, kidneys and intestine for histopathological examination by light and electron microscope after staining with appropriate stains.

\section{Statistics:}

The data were analyzed using one-way analysis of variance and repeated measures and the differences among group means were analyzed using the Dunnett's multiple comparisons test. A p-value of $<0.05$ was considered significant and p-value of $<0.01$ was considered highly significant. The Graph Pad Prism software (version 5) was employed for the statistical analysis.

\section{RESULTS}

\section{Body weight and weight gain}

Significant reduction $(p<0.05)$ of body weight in group B was recorded start from $2^{\text {nd }}$ month till $4^{\text {th }}$ month when compared to that of control group. Addition of yeast to contaminated diet in the group $\mathrm{C}$ show increase in body weight nearly similar to control when compared with group B (Fig. 1). Significant decrease in weight gain $\left({ }^{* *} \mathrm{p}<0.01\right)$ were observed in rats of group B compared to that of control. The decrease in weight gain was highest in $2^{\text {nd }}$ month till $4^{\text {th }}$ month. While, no significant reduction could be recorded in weight gain of the group C compared to the control (Fig. 2).

\section{Histopathology}

Histopathological changes were obvious in the liver, kidneys and intestine. The intensity of the lesions was more pronounced by increase of experimental period. Microscopically, the livers of the rats fed contaminated diet with fungal material AF and DAS for 4 months revealed fatty degeneration of hepatocytes (Fig. 3), focal areas of necrosis (Fig. 4), activation of Kupffer's cells, increase the mitotic figures and start early steps for preneoplastic changes of hepatic cells in the form of megalocytosis (Fig. 5), nuclear pleomorphism (Fig. 6), multinucleated hepatocytes (Fig. 7) and increased number of binucleated hepatocytes in the hepatic lobules and newly formed bile ducts (Fig. 8), ultrastructurally showed presence of numerous fat globules in the hepatic cell and presence of bundle of collagen fiber in between hepatic cells (Fig. 9).

Treatment with yeast for four months markedly relieved the hepatic changes compared to group B animals. Microscopically the liver of group $\mathrm{C}$ revealed mild congestion of the hepatic vasculature and necrobiotic changes of hepatocytes, moderate activation of Kupffer's cells, with mild vacuolar degeneration. The number of binucleated hepatocytes was more or less similar to the control group. Ultrastructurally, the hepatic cells were rich in cell organelles and the fat storing cells were hypertrophied and contain numerous fat globules.

Kidneys of group B had glomerular cellular reaction, periglomerular fibrosis and degeneration of the tubular epithelial lining (Fig. 10, 11), ultrastructurally showed presence of lysosomes appeared as electron dense bodies in tubular epithelium and fine collagen fiber in between tubules.

The most pronounced lesions observed in kidneys of group $\mathrm{C}$ were slight increases of mesangial cell and matrix in the glomeruli and mild tubular degeneration. There was also slight periglomerular reaction (Fig. 12). Ultrastructurally, peculiar to this group in this period a numerous plasma cells in the interstitial tissue of the kidney could be observed. Also, the tubular epithelium showed mild degenerative changes with presence of numerous lysosomes (Fig. 13).

Intestinal lesions of group B consisted of degeneration of intestinal epithelial cells, congestion, hemorrhage in the villous core associated with lymphocytic cell infiltration ended by villous atrophy (Fig. 14). There were mild lymphocytic activation and at the end of experiment turned to lymphocytic depletion. The addition of yeast to the fungal-containing diet significantly ameliorated the adverse effects of fungal toxin on the intestine and improves the immune response in the intestine where prominent lymphoid follicle hyperplasia was characteristic lesion of group C animals (Figs.15). Lymphocytic cell infiltration in the villous core with slight increase of goblet cells was observed. 


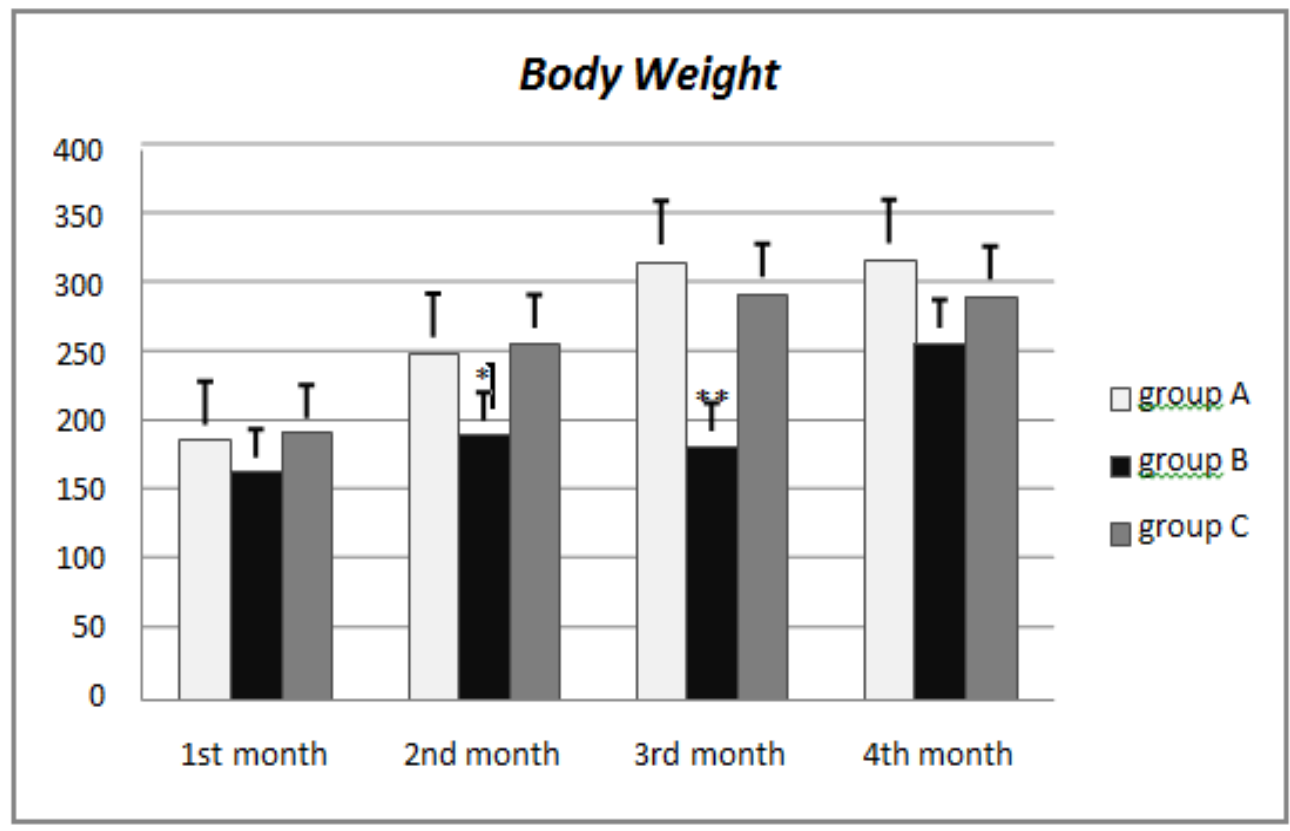

(Fig. 1): Histogram showing the body weight $/(\mathrm{g})$ of control and treated groups during the experimental period. $\left(\mathrm{p}^{*}<0.05 ; \mathrm{p}^{* *<}<0.01\right)$

Group A- control group Group B- fungal contaminated feed Group C-contaminated feed + yeast

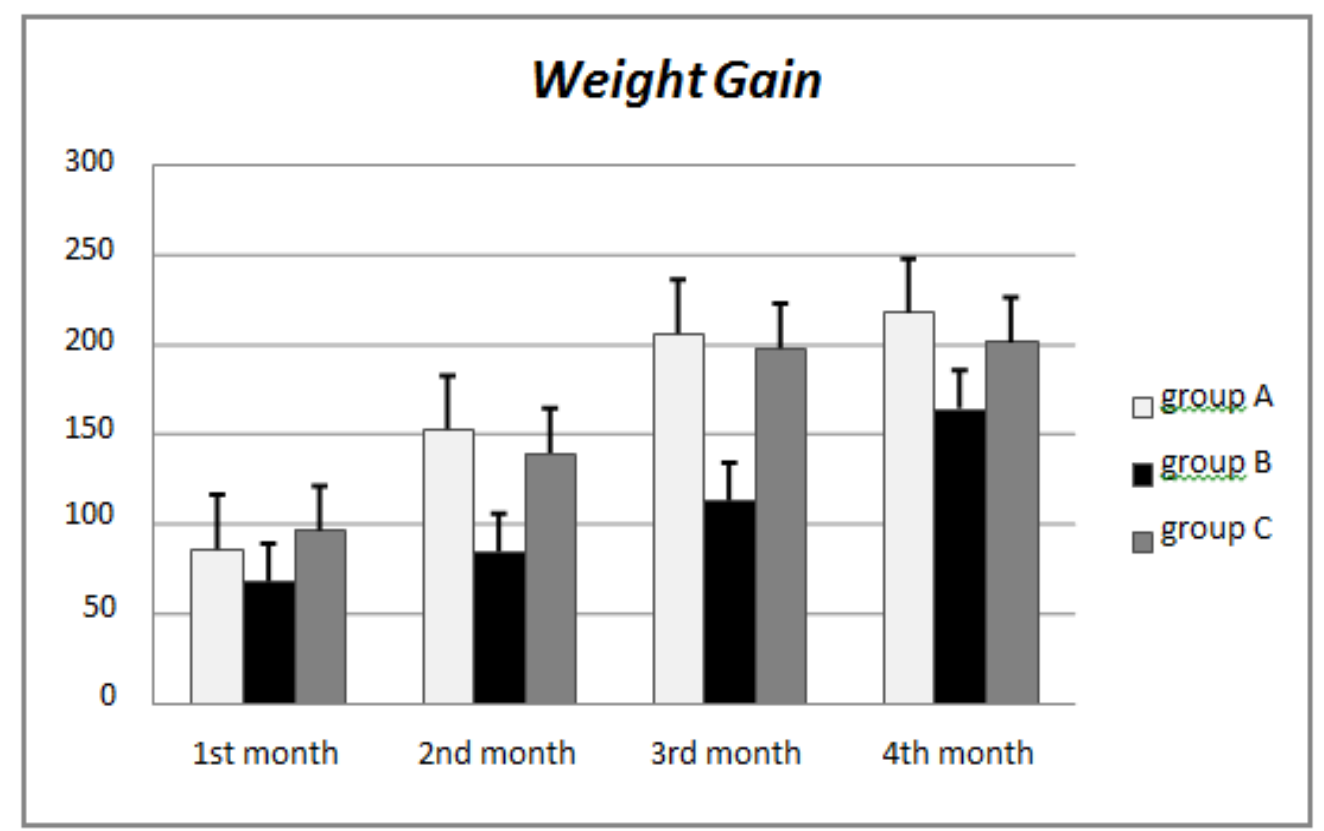

(Fig. 2): Histogram showing the weight gain $/(\mathrm{g})$ of control and treated groups during the experimental period. $\left(\mathrm{p}^{*}<0.05 ; \mathrm{p}^{* *<0.01)}\right.$

Group A- control group Group B- fungal contaminated feed Group C-contaminated feed + yeast 


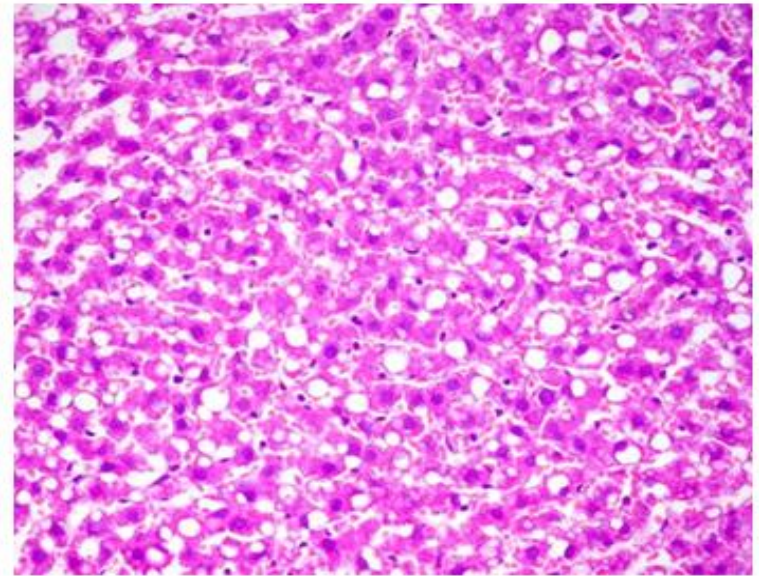

Fig. (3): Light micrograph of liver belong to group B showing fatty degeneration. (H\&E $\mathrm{x} 400$ )

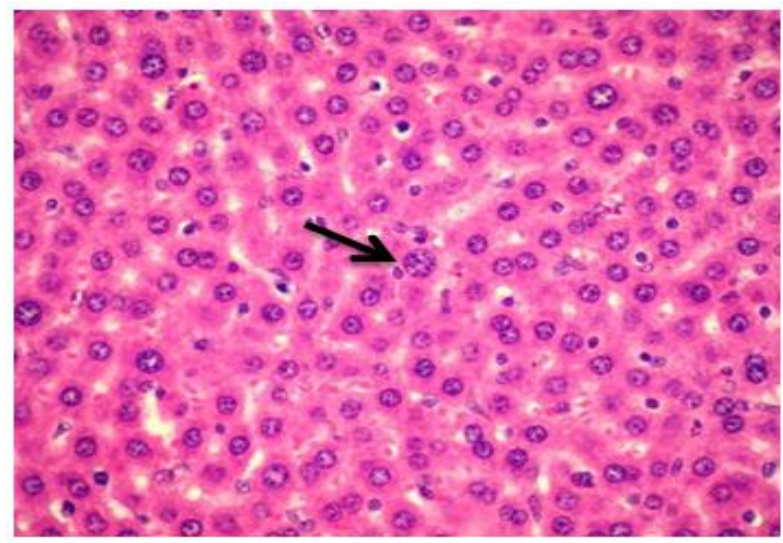

Fig. (5): Light micrograph of liver belong to group B showing karyomegaly (arrow) and increased binucleated hepatocytes in the afield. (H\&E x400)

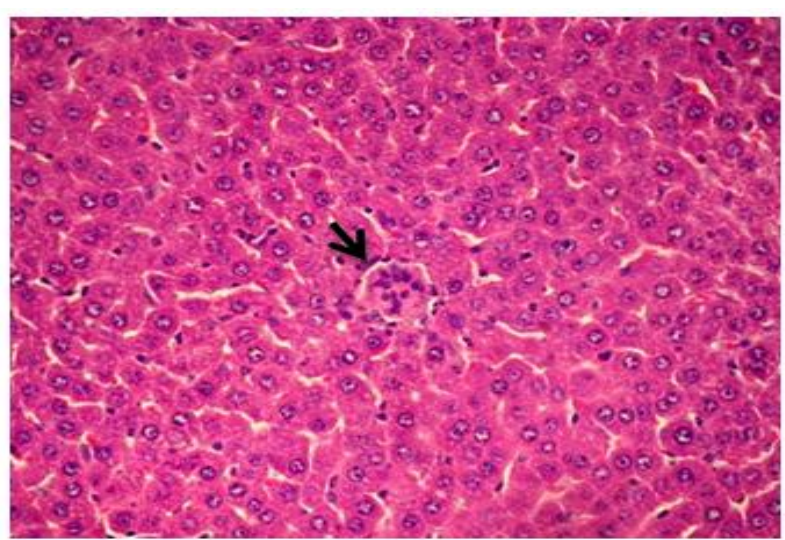

Fig. (7): Light micrograph of liver belong to group B showing abnormal multinucleated hepatocyte (arrow). (H\&E x400)

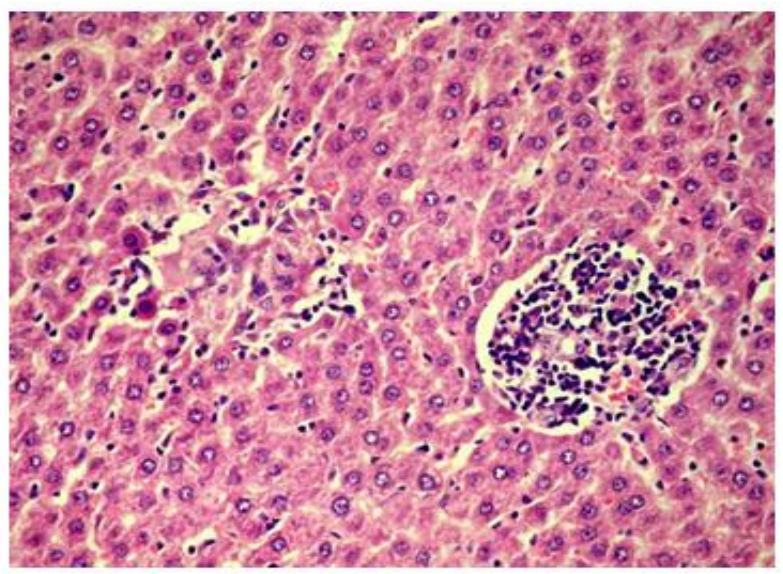

Fig. (4): Light micrograph of liver belong to group B showing focal area of hepatic cell necrosis with mononuclear cellular infiltration and diffuse activation of Kupffer's cells. (H\&E $\mathrm{x} 400$ )

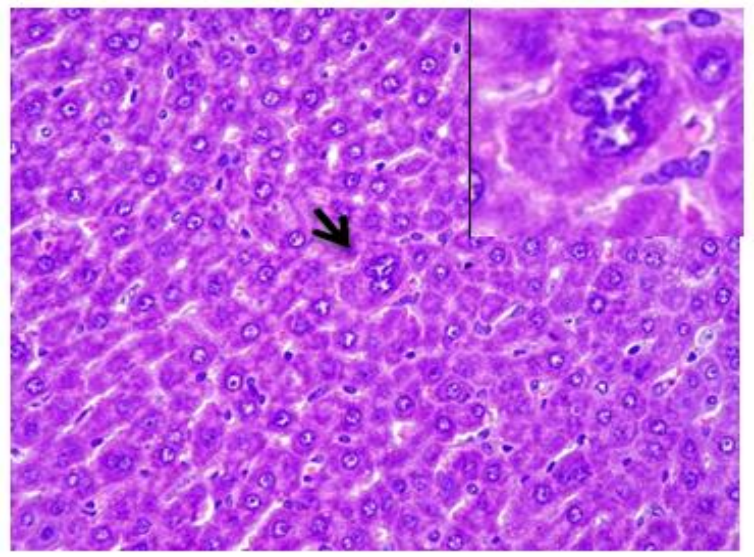

Fig. (6): Light micrograph of liver belong to group B showing abnormal hepatic cell with dysplastic nucleus of hepatocyte (arrow). (H\&E $\mathrm{x} 400$ )

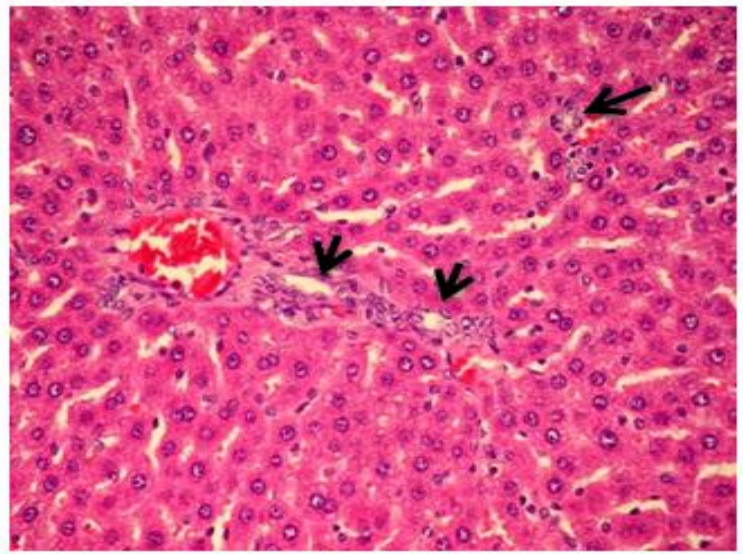

Fig. (8): Light micrograph of liver belong to group B showing presence of numerous newly formed bile ducts (arrows). (H\&E x400) 

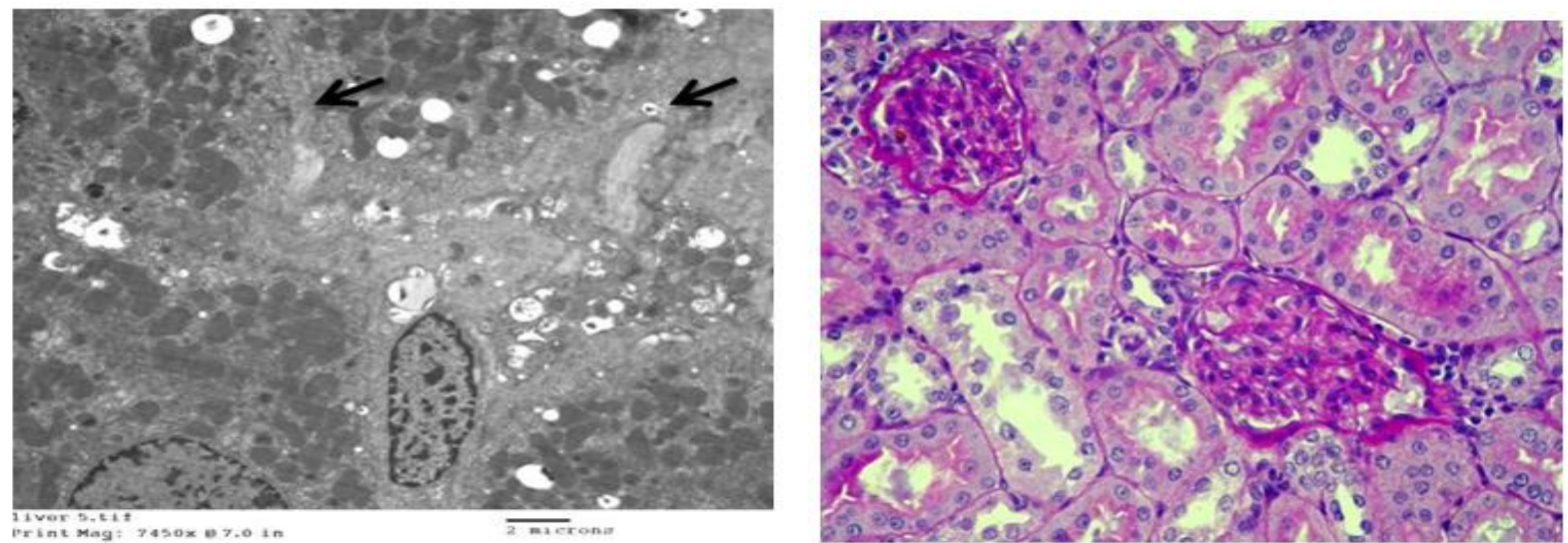

Fig. (9): TEM of liver belong to group B showing presence of bundle of collagen fiber in between hepatic cells (arrows) with presence of hypertrophyed kupffer cell and fat storing cell. scale bar $=2$ microns

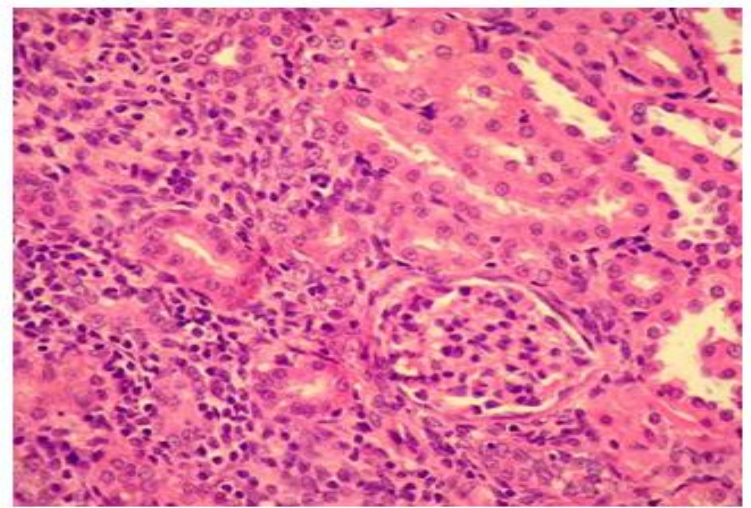

Fig. (11): Light micrograph of kidney belong to group $\mathrm{B}$ showing Periglomerular fibrosis and interstitium cellular reaction of lymphocetic and fibrocytic cells. (H\&E)

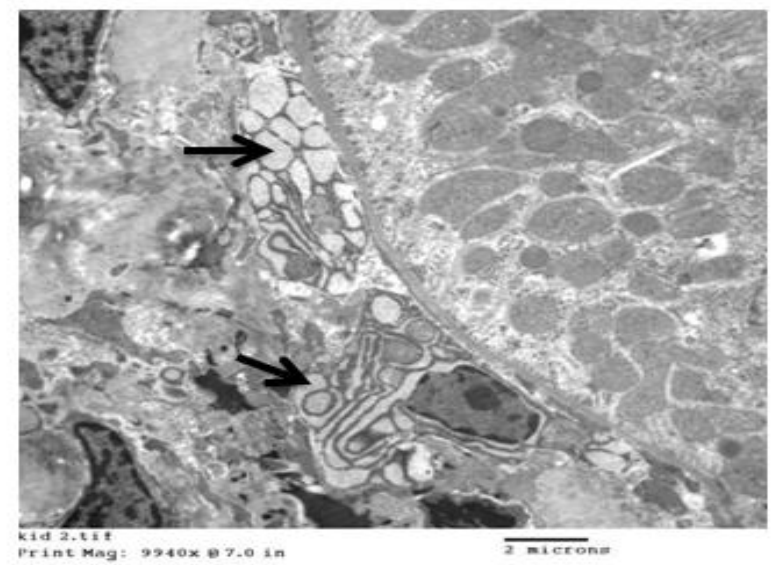

Fig. (13): TEM of kidney belong to group $\mathbf{C}$ showing presence of numerous plasma cells in the interstitial tissue rich in dilated RER forming Russell's bodies (arrows) and tubular epithelium contain small electron dense bodies (lysosomes). scale bar $=2$
Fig. (10): Light micrograph of kidney belong to group B showing thickening of glomerular basement membrane and increased mesangial matrix. (PAS stain $x 400$ )

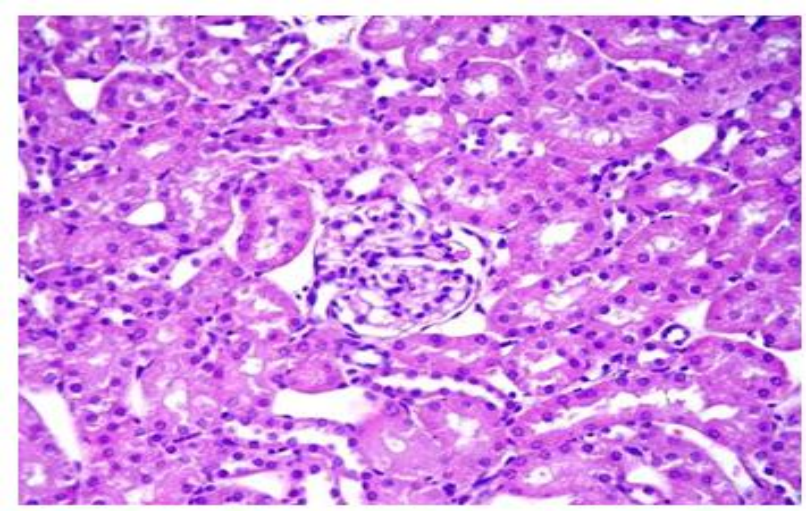

Fig. (12): Light micrograph of kidney belong to group $\mathrm{C}$ showing glomeruli with thin Bawman`s capsule and mild tubular degeneration. (H\&E)

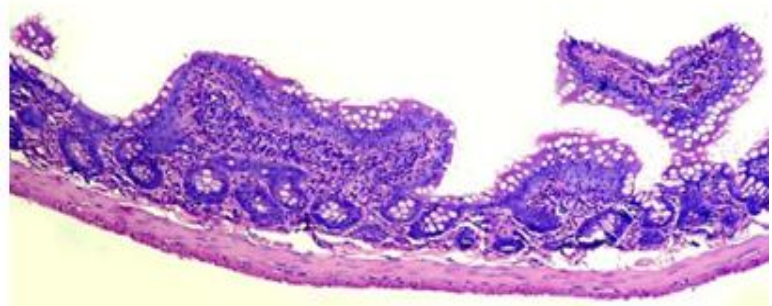

Fig. (14): Light micrograph of intestine belong to group B showing villous atrophy. (H\&E x100) 


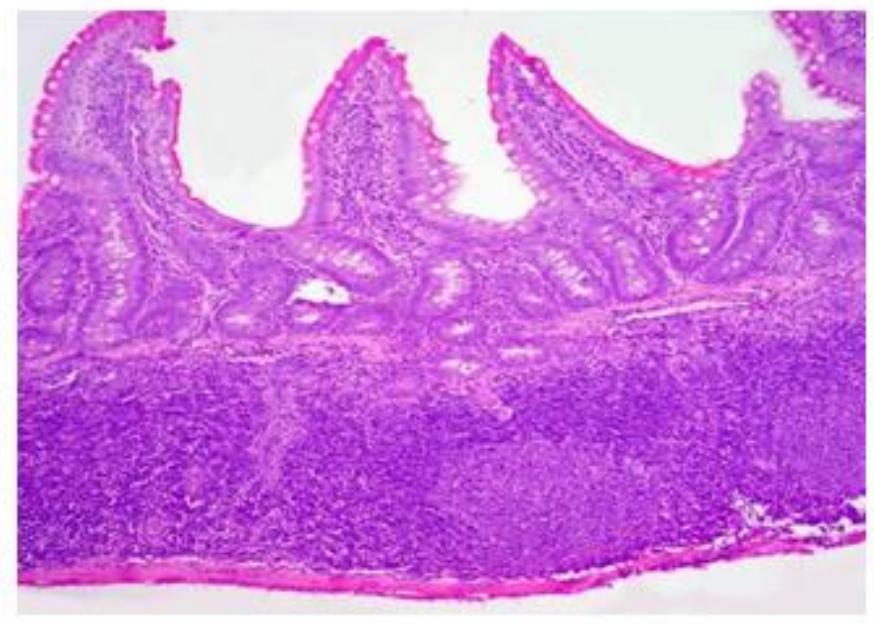

Fig. (15): Light micrograph of intestine belong to group $C$ showing hyperplasia of payer`s patches lymphoid follicle. (H\&E x 100)

\section{DISCUSSION}

The administration of contaminated diet with aflatoxins and diacetoxyscirpenol (DAS) for a period of 4 months to rats significantly reduces the body weight (BW) and weight gain. The weight reduction depends on concentration of mycotoxin and on time of experiment. A decrease in the animal's weight is one of the more common characteristics of a continual ingestion of AFB1 (Smith and Ross, 1991; Quezada et al., 2000; Madrigal-Santillán et al., 2006). Contrary to this, Sklan et al. (2001) reported that no decreases in growth or feed efficiency were observed when T-2, DAS, or a mixture of these mycotoxins was fed to chicks for 35 days. In addition, Casado et al. (2001) observed neither the body weight nor the weight gain varied significantly in the mice fed a mixture of $\mathrm{AFB}_{1}$ and fumonisins for about 90 days.

\section{Treated groups}

On the other hand, the current study showed that coadministration of yeast and mycotoxins, enhanced growth performance and resulted in a significant recovery in body weight. These findings are similar to previous studies; Addition of Saccharomyces cerevisiae $(\mathrm{Sc})$ to diets could improve growth performance (Onifade et al., 1999 and Darwish et al., 2011). Madrigal-Santillán et al. (2006) demonstrated that animals treated with $\mathrm{Sc}$ plus $\mathrm{AFB}_{1}$ gained considerable weight in the third and the sixth week of the assay; which was more than double the usual level reached by $\mathrm{AFB}_{1}$ treated mice. Yeast viability seems critical for such growthpromoting effect, since it was not observed when inactive yeast was incorporated into the feed (Métailler and Huelvan, 1993 and Oliva-Teles and Gonçalves, 2001). Moreover, digestion of yeast cells releases active compounds like polyamines, proteases and phosphatases, which could be beneficial for the digestive process (Zanello et al., 2009).

\section{Histopathology}

The co-exposure of rat to contaminated diet with aflatoxins AF diacetoxyscirpenol (DAS) induced many histopathological changes in the liver of rats and the severity of such changes was time dependent. In this respect, a study by Ozen et al. (2009) found that lesions of aflatoxicosis in chicks were apparently a dose-dependent mild to severe vacuolar degeneration with irregularly shaped vacuoles in hepatocytes. Generally, it is believed that lipid accumulation in liver produced by aflatoxicosis arises as a result of impaired lipid transport rather than increased lipid biosynthesis. There were also diffuse necrobiotic changes associated activation of Kupffer's cells were progressively seen. Similar findings were observed by Sakr et al. (2006) in rats treated with AFB1 for 6 weeks. Focal areas of necrosis infiltrated with mononuclear cells were found moreover, apoptosis and hepatocytes showing mitosis were observed predominantly in the periportal regions in some animals. These findings are in agreement with Darwish et al. (2011) who reported that mice treated with AFs $(0.7 \mathrm{mg} / \mathrm{kg}$ b.w. $)$ for a week showed an increased numbers of both apoptotic cells and mitoses in the liver. In addition, Ihara et al. (1997) found that T-2 toxin at dose of 2$5 \mathrm{mg} / \mathrm{kg}$ strongly induces apoptotic cellular lesions in the livers of mice. In addition, multinucleated cells (formed by cell fusion rather than division) can be formed in rats after administration of 2,3,7,8tetrachloro-dibenzo-p-dioxin (Jones and Butler 1975 and Gopinath et al., 1987). Hussain et al. (2009) reported that treatment of rats with $\mathrm{AF}$ resulted in newly formed bile ducts in the liver. The hyperplasia 
of the bile ducts is a characteristic lesion of aflatoxicosis and may be due to the direct effect of aflatoxins on the biliary cells or the production of prostaglandins during peroxidation of lipids (Quist et al., 2002; Hashem and Mohamed, 2009). There were increased numbers of binucleated hepatocytes indicating regeneration activities in the liver cells accompanied chronic toxicity of aflatoxin and these results are compatible with some authors who reported that aflatoxin could induce regeneration activities in the liver by increasing mitosis and binucleated hepatocytes (Mohamed, 1996; Yousef, 2009). Liver also showed karyomegalic nuclei of hepatocytes, and other enlarged nuclei of hepatocytes showed pleomorphism. These findings were similarly reported by (Yener et al., 2009 and Colakoglu and Donmez, 2012) in rats and ram, respectively.

Group (C) showed significantly less pathological changes including vacuolar degeneration, dysplastic hepatocytes, bile-duct proliferation and periportal fibrosis, as compared with group B-treated rats. These results are in accordance with those of Baptista et al. (2008) who found that the yeast strains Y1026 and Y904 were able to reduce ALT and AST activity and reduce liver damage induced by aflatoxins in Wistar rats.

The kidneys were a target organ in AF metabolism (Valdivia et al., 2001; Del Bianchi et al., 2005), and one of excretory routs of DAS (Wang et al., 1990). So that the administration of rats to a mixture of $\mathrm{AF}$ and DAS contaminated diet produced swollen glomeruli which filled the Bowman's capsules as a result of either distension of glomerular capillaries with RBCs or increased glomerular hypercellularity then progressed to glomerular swelling as a result of increasing mesangial matrix and thickening of glomerular basement membranes. These findings are in agreement with previous reports, which reported that, AF can alter structure and function of the kidney including thickening of the glomeruli basal membrane (Valdivia et al., 2001 and Kumar and Balachandran, 2009). Additionally, Hussain et al. (2008) observed that aflatoxin in chicken induced glomerular hypertrophy and proliferation of mesangial cells. Hashem and Mohamed, (2009) found that treatment of broiler chicks with aflatoxins for 21 days resulted in proliferation of the glomerular endothelial cells with thickening of basement membranes of glomerular capillaries of most treated chicks. There was also precipitation in Bowman's space observed in some glomeruli. Similar lesion was detected by Chen et al. (2008) in pigs fed a diet containing $1 \mathrm{mg} / \mathrm{kg}$ deoxynivalenol (DON) and $250 \mu \mathrm{g} / \mathrm{kg}$ zearalenone (ZON) for 6 weeks.
There were degeneration and PAS positive material in tubular epithelium was observed in some cases. In coincide to these changes, it was reported that treatment with aflatoxins caused degeneration in renal tubular epithelial cells (Dhanasekaran et al., 2009; Kumar and Balachandran, 2009 and Saddiq and Kalifa, 2011). Also, Hoerr et al. (1982) reported that treatment with a single dose of diacetoxyscirpenol $(3.5 \mathrm{mg} / \mathrm{kg})$ in a chicken resulted in necrosis of renal tubular epithelium. Additionally, the observation of earlier studies of Wannop, (1961); Newberne et al. (1967) and Brown et al. (1987) in turkeys and ducks; found that aflatoxin induces nephrosis with periodic acid Schiff-positive granules in proximal tubular epithelial cells.

The addition of yeast to mycotoxin contaminated diet showed improvement in adverse effects on kidneys, which revealed minimal evidence of renal tubule injury or hypercellularity of glomeruli. This is in agreement with, Darwish et al. (2011) who found that mice received $S$. cerevisiae before AFs gavage, showed a significant amelioration in serum biochemical parameters and improvement in liver and kidney tissues architecture.

The characteristic pathological alteration in the intestine includes increase in number of goblet cells and degenerative changes in the enterocytes progressed to necrosis of the villous tip observed in rats of group B. equivalent to these, catarrhal and necrotic enteritis were observed in layer chicken fed $0.5 \mathrm{ppm}$ of $\mathrm{AF}$ from 0 to 12 weeks of age by Gounalan et al. (2005). Furthermore, Hoerr, (1998) demonstrated that trichothecenes cause harmful injury to the mucosa, destroying cells on the tips of villi and radiomimetic injury to rapidly dividing crypt epithelium. Moreover, DAS inhibits protein synthesis result in necrosis of epithelial cells. This can cause bleeding into the intestinal lumen, increased frequency of ulcers and damage to the absorptive surfaces causing reduced nutrient uptake.

There were villous core alterations observed at different time of experiment, started by hyperemia and congestion then hemorrhages and ended by increased lymphocytic and mononuclear infiltrations resulted in shortening and thickening of villi. This is supported by Sklan et al. (2003) who found that feeding of T-2 toxin or diacetoxyscirpenol at levels up to $1 \mathrm{ppm}$ for 32 days to poults caused changes in small intestinal morphology, especially in the jejunum villi which become shorter and thinner. Also, there are many reports indicated that a chronic exposure to low levels of AFB 1 would decrease the unit absorptive surface of small intestine in broilers (Kana et al., 2010 and Yunus et al., 2011). There was villous atrophy recognized in rats. This result is in accordance with, Fairchild et al. (2005) who found that the feeding of diacetoxyscirpenol (DAS) 
and fusaric acid (FA) to poults decreased enterocyte height at mid villus by $59 \%$. There were associated changes in intestinal lymphoid follicles which showed mild activation of intestinal lymphoid follicle started at $1^{\text {st }}$ month then regressed at last month. In this context, Pestka, (2003) reported that mice fed Deoxynivalenol (DON) exhibited elevated membrane IgA bearing cells and elevated Peyer's patch (PP) lymphocytes resulting in production of significantly more IgA, indicating that feed-borne DON promotes the polyclonal activation and expansion of IgA secreting cells in PPs in the intestine and may contribute to increased systemic concentrations of $\operatorname{IgA}$. On the other hand, dietary AFB 1 has been found by Çelik et al. (2000) to result in degeneration of follicle associated epithelium (FAE) in bursa of Fabricius and destruction of thymic cortex in chicken. In addition, Kumar et al. (2003) found that aflatoxin B1 either alone or in combination with ochratoxin A (OCA) at dose 0.5 ppm $\mathrm{AFB}_{1}$ and 1 ppm OCA for 5 weeks induced atrophy of bursa of fabricius in broiler chickens.

The addition of $S$. cerevisiae to mycotoxinscontaining diet significantly improved the intestinal pathological alteration and induced intestinal lymphoid follicles hyperplasia compared to the intestine of group B rats. These results were supported by study of Buts et al. (1990) who recorded that the level of secretory immunoglobulin A ( $\operatorname{sg} \mathrm{A}$ ) increased $57 \%$ in the duodenal fluid and the secretory component of immunoglobulins enhanced $69 \%$ in villus cells and $80 \%$ in crypt cells of rats treated with the high dose of yeast. Additionally, Santin et al. (2003) stated that the cell wall of Saccharomyces cerevisiae improve the intestinal mucosa aspects and returned the improvement in performance of broilers fed aflatoxin contaminated diets to supplementation with cell wall of $S$. cerevisiae. These benefits of Saccharomyces cerevisiae may be due to stimulation of the immune response (Savage et al., 1996), alteration of intestinal microbial environment (Newman, 1994) and producing enzymes for gut microbiota to enhance the nutrients bioavailability (Parlat et al., 2001 and Abousadi et al., 2007).

It has been concluded that co-administration of Saccharomyces cerevisiae and a mixture of aflatoxins plus diacetoxyscirpenol ameliorate the intensity and prevalence of lesions reported in different organs when compared to lesions of the control positive group $\mathrm{B}$. in addition S.cerevisiae positively enhance growth performance and immune defense mechanism against the administrated mycotoxins

\section{REFERENCES}

Abousadi, A.M.; Rowghani, E. and Honarmand, M.E. (2007): The efficacy of various additives to reduce the toxicity of aflatoxin B1 in broiler chicks. Iranian Journal of Veterinary Research 8: 144-150.

Baptista, S.; Abdalla, L.; Aguiar, L.; Baptista, D.; Micheluchi, S.; Zampronio, C.; Pires, S.; Glöria, M.; Calori-Domingues, A.; Walder, M.; Vizioli, R. and Horii, J. (2008): Utilization of diets amended with yeast and amino acids for t he control of aflatoxicosis. World Journal of Microbiology and Biotechnology 24: 2547-2554.

Basmacioglu, H.; Oguz, H.; Ergul, M.; Col, R. and Birdane, Y.O. (2005): Effect of dietary esterified glucomannan on performance, serum biochemistry and haematology in broilers exposed to aflatoxin. Czech Journal of Animal Science 50: 31-39.

Betina, V. (1989): Biological effects of mycotoxins. In: V. Betina (Ed), Mycotoxins: Chemical, Biological and Environmental Aspects. Elsevier, Amsterdam. PP: 42-58.

Brown, T.P.; Fletcher, O.J.; Osuna, O. and Wyatt, R.D. (1987): Microscopic and ultrastructural renal pathology of oosporein-induced toxicosis in broiler chicks. Avian Diseases 31: 868-877.

Buts, J.P.; Bernasconi, P.; Vaerman, J.P. and Dive, C. (1990): Stimulation of secretory $\operatorname{IgA}$ and secretory component of immunoglobulins in small intestine of rats treated with Saccharomyces boulardii. Dig. Dis. Sci. 35: 251-256.

Casado, J.M.; Theumer, M.; Masih, D.T.; Chulze, S. and Rubinstein, H.R. (2001): Experimental subchronic mycotoxicoses in mice: individual and combined effects of dietary exposure to fumonisins and aflatoxin B1. Food and Chemical Toxicology 39: 579-586.

Çelik, I.; Ŏ̆uz, H.; Demet, Ö.; Dönmez, H.H.; Boydak, M.; Sur, E. (2000): Efficacy of polyvinylpolypyrrolidone in reducing the immunotoxicity of aflatoxin in growing broilers. Br. Poult. Sci. 41: 430-439.

Chen, F.; Ma, Y.; Xue, C.; Ma, J.; Xie, Q.; Wang, G.; Bi, Y. and Cao, Y. (2008): The combination of deoxynivalenol and zearalenone at permitted feed concentrations causes serious physiological effects in young pigs. J. Vet. Sci. 9: 39-44.

Colakoglu, F. and Donmez, H.H. (2012): Effects of Aflatoxin on Liver and Protective Effectiveness of Esterified Glucomannan in Merino Rams. The Scientific World Journal Volume 2012, Article ID 462925, 5 pages.

Darwish, H.R.; Omara, E.A.; Abdel-Aziz, K.B.; Farag, I.M.; Nada, S.A. and Tawfek, N.S. (2011): Saccharomyces cerevisiae modulates 
Aflatoxin-induced toxicity in male Albino mice. Report and Opinion 3: 32-43.

Del Bianchi, M.; Oliveira, C.A.F.; Albuquerque, R.; Guerra, J.L. and Correa, B. (2005): Effects of prolonged oral administration of aflatoxin $\mathrm{B}_{1}$ and fumonisin $\mathrm{B}_{1}$ in broiler chickens. Poult. Sci. 84: 1835-1840.

Dhanasekaran, D.; Panneerselvam, A. and Thajuddin, N. (2009): Evaluation of aflatoxicosis in hens fed with commercial poultry feed. Turk. J. Vet. Anim. Sci. 33: 358391.

Dorner, J.W. (2008): Management and prevention of mycotoxins in peanuts. Food Addit. Contam. Part A Chem. Anal. Control Expo. Risk Assess. 25: 203-208.

Fairchild, A.S.; Grimes, J.L.; Porter, J.K.; Croom Jr., W.J.; Daniel, L.R. and Hagler, Jr., W.M. (2005): Effects of diacetoxyscirpenol and fusaric acid on poults: individual and combined effects of dietary diacetoxyscirpenol and fusaric acid on turkey poult performance. Int. J. Poult. Sci. 4: 350355.

Gimeno, A. (1979): Thin layer chromatographic determination of aflatoxins, ochratoxins, sterigmatocystin, zearalenone, citrinin, T-2 toxin, diacetoxyscirpenol, penicillic acid, patulin and penitrem A. J. Assoc. Offic. Anal. Chem. 62: 579-585.

Girish, C.K. and Smith, T.K. (2008): Effects of feeding blends of grains naturally contaminated with Fusarium mycotoxins on small intestinal morphology of turkeys. Poultry Science 87: 1075-1082.

Gopinath, C.; Prentice, D.E. and Lewis, D.J. (1987): The liver. In Atlas of Experimental Toxicological Pathology (G.A. Grasham, ed.), Vol. 13, pp. 43-60. MTP Press Limited, Lancaster, England.

Gounalan, S.; Balachandran, C. and Manohar, B.M. (2005): Immunopathological effects and induction of apoptosis in spleen and thymus in layer chicken in aflatoxicosis. International conference on advance Veterinary practice in medicine and surgery augmenting health and production, Chennai, 21-25 June, 2006.

Hashem, M.A. and Mohamed, M.H. (2009): Haemato-biochemical and pathological studies on aflatoxicosis and treatment of broiler chicks in Egypt. Veterinaria Italiana 45: 323- 337

Hoerr, F.J. (1998): Pathogenesis of enteric diseases. Poult. Sci. 77: 1150-1155.

Hoerr, F.J.; Carlton, W.W.; Yagen, B. and Joffe, A.Z. (1982): Mycotoxicosis caused by either T-2 toxin or diacetoxyscirpenol in the diet of broiler chickens. Fund. Appl. Toxicol. 2: 121124.
Hussain, S.; Khan, M.Z.; Khan, A.; Javed, I. and Asi, M.R. (2009): Toxico-pathological effects in rats induced by concurrent exposure to aflatoxin and cypermethrin. Toxicon 53: 3341.

Hussain, Z.; Khan, M.Z. and ul-Hassan, Z. (2008): Production of aflatoxins from Aspergillus flavus and acute aflatoxicosis in young broiler chicks. Pak. J. Agri. Sci. 45: 95-102.

Ihara, T.; Sugamata, M.; Sekijima, M.; Okumura, H.; Yoshino, N. and Ueno, Y. (1997): Apoptotic cellular damage in mice after T-2 toxin-induced acute toxicosis. Natural Toxins 5: 141-5.

Jones, G. and Butler, W.H. (1975): Morphology and spontaneous neoplasia. In Mouse Hepatic Neoplasia (W.M. Butler and P.M. Newberne, eds.), pp 21-59. Elsevier, Oxford, UK.

Jouany, J.P. (2007): Methods for preventing, decontaminating and minimizing the toxicity of mycotoxins in feeds. Animal Feed Science and Technology 137: 342-362.

Kana, J.R.; Teguia, A. and Tchoumboue, J. (2010): Effect of dietary plant charcoal from Canarium schweinfurthii Engl. and maize cob on aflatoxin $\mathrm{B} 1$ toxicosis in broiler chickens. Adv. Anim. Biosci. 1, 462-463.

Kumar, P.A.; Satyanarayana, M.L.; Vijayasarathi, S.K.; Gowda, R.N.S. and Rao, S. (2003): Pathology of lymphoid organs in aflatoxicosis and ochratoxicosis and immunomodulatory effect of vitamin $\mathrm{E}$ and selenium in broiler chicken. Indian Journal of Veterinary Pathology 27: 102-106.

Kumar, R. and Balachandran, C. (2009): Histopathological changes in broiler chickens fed aflatoxin and cyclopiazonic acid. Vet. Arhiv. 79: 31-40.

Madrigal-Santillán, E.; Madrigal-Bujaidar, E.; Márquez-Márquez, R. and Reyes, A. (2006): Antigenotoxic effect of Saccharomyces cerevisiae on the damage produced in mice fed with aflatoxin B1contaminated corn. Food and Chemical Toxicology 44: 2058-2063.

Métailler, $R$. and Huelvan, C. (1993): Uitilisation des levures dans l'alimentation du juvénile de bar (Dicentrarchus labrax). In: Kaushik, S. and Luquet, P. (Eds.): Fish Nutrition in Practice Les Colloques, Institut National de la Recherche Agronomique, Paris, 61: 945-948.

Mohamed, N.A. (1996): Experimental studies on the combined effect of some amino acids, minerals and vitamins on the pathological changes of aflatoxin B1 in albino rats. M.V.Sc. Degree in vet. Pathology and clinical pathology, Assiut University.

Moslehi-Jenabian, S.; Pedersen, L.L. and Jespersen, L. (2010): Beneficial effects of probiotic and food borne yeasts on human health. Nutrients 2: 449-473. 
Newberne, P.M.; Carlton, W.W. and Wogan, G.N. (1967): Hepatomas in rats and hepatorenal injury in ducklings fed peanut meal or Aspergillus flavus extract. Pathol. Vet. 1: 105132.

Newman, K.E. (1994): Mannanoligosaccharide, natural polymers with significant impact on the gastrointestinal microflora and immune system. In: Biotechnology in the feed industry. T.P. Lyons and K.A. Jaques (eds.). Kentucky: Alltech Inc. pp: 167-174.

Oguz, H. (1997): The preventive efficacy of polyvinylpolypyrrolidone (PVPP) alone and its combination with the other adsorbents into broiler feeds against aflatoxicosis. Ph. D. Thesis. Institute of Health Sciences, University of Selçuk, Konya.

Oliva-Teles, A. and Gonçalves, P. (2001): Partial replacement of fish meal by brewer's yeast (Saccharomyces cerevisiae): in diets for sea bass (Dicentrarchus labrax): juveniles. Aquaculture 202: 269-278.

Onifade, A.; Obiyan, R.; Onipede, E.; Adejumo, D.; Abu, O. and Babatunde, G. (1999): Assessment of the effects of supplementing rabbit diets with a culture of Saccharomyces cerevisiae using growth performance, blood composition and clinical enzyme activities. Anim. Feed Sci. Technol. 77: 25-32.

Ozen, H.; Karaman, M. and Cigremis, Y. et al., (2009): Effectiveness of melatonin on aflatoxicosis in chicks. Research in Veterinary Sciences 86: 485-489. 2009.

Parlat, S.S.; Ozcan, M.H. and Oguz, H. (2001): Biological Suppression of aflatoxicosis in Japanese quail (Coturnix coturnix japonica) by dietary addition of yeast (Saccharomyces cerevisiae). Research in Veterinary Science 71: 207-211.

Pestka, J.J. (2003): Deoxynivalenol-induced IgA production and $\operatorname{Ig} \mathrm{A}$ nephropathy-aberrant mucosal immune response with systemic repercussions. Toxicol. Lett. 140-141: 287295.

Placinta, C.M.; D'Mello, J.P.F. and Macdonald, A.M.C. (1999): A review of worldwide contamination of cereal grains and animal feed with Fusarium mycotoxins. Animal Feed Science and Technology 78: 21-37.

Quezada, T.; Cuellar, H.; Jaramillo-Juarez, F.; Valdivia, A.G. and Reyes, J.L. (2000): Effects of aflatoxin $\mathrm{B}(1)$ on the liver and kidney of broiler chickens during development. Comp. Biochem. Physiol.C Toxicol. Pharmacol. 125: 265-272.

Quist, C.F.; Bounous, D.I.; Kilburn, T.V.; Nettles, V.F. and Wyatt, R.D. (2002): The effect of dietary aflatoxin on wild turkey poultry. J. Wildl. Dis. 36: 436-444.

Romer, R.T. (1975): Qualitaitve/quantitiatve analysis for detection and estimation of aflatoxin
(Romer mini column method). J. Assoc. Off. Anal. Chem. 58: 500-506.

Saddiq, A.A. and Kalifa, S.A. (2011): Impact of fungal content of some Arabic nuts to induce kidney toxicity and agonistic action of natural resources. African Journal of Microbiology Research 5: 1046-1056.

Sakr, S.A.; Lamfon, H.A. and El-Abd, S.F. (2006): Ameliorative effect of Lupinus seeds on histopathological and biochemical changes induced by Aflatoxin-B1 in rat liver. Journal of Applied Science Research 2: 290-295.

Santin, E.; Paulilo, A.C.; Maiorka, A.; Nakaghi, L.S.O.; Macan, M. and de Silva, A.V.F., et al. (2003): Evaluation of the efficiency of Saccharomyces cerevisiae cell wall to ameliorate the toxic effects of aflatoxin in broilers. International Journal of Poultry Science 2: 241-344.

Savage, T.F.; Cotter, P.F. and Zakrzewska, E.I. (1996): The effect of feeding mannan oligosaccharide on immunoglobulins, plasma IgG and bile IgA of Wordstad MW male turkeys. Poultry Science 75: 53-64.

Shotwell, O.L.; Hesseltine, C.W.; Stubblefield, R.D. and Sorenson, G.W. (1966): Production of aflatoxin on rice. Appl. Microbiol. 14: 425 428.

Sklan, D.; Klipper, E. and Friedman, A. (2001): The effect of chronic feeding of Diacetoxyscirpenol, T-2 toxin, and Aflatoxin on performance, health, and antibody production in chicks. J. Appl. Poultry Res. 10: 79-85.

Sklan, D.; Shelly, M.; Makovsky, B.; Geyra, A.; Klipper, K. and Friedman, A. (2003): The effect of chronic feeding diacetoxyscirpenol and T-2 toxin on performance, health, small intestinal physiology and antibody production in turkey poults. Br. Poult. Sci. 44: 46-52.

Smith, J. and Ross, K. (1991): Detoxigenic aspergilli. In: Smith, J.E., Henderson, R.S. (Eds.), Mycotoxins and Animal Foods. CRC Press, Boca Raton, pp. 101-118.

Speijers, G.J.A. and Speijers, M.H.M. (2004): Combined toxic effects of mycotoxins Toxicology Letters 153: 91-98.

Valdivia, A.G.; Martinez, A.; Damian, F.J.; Quezada, T.; Ortiz, R.; Martinez, C.; Llamas, J.; Rodriguez, M.L.; Yamamoto, L.; Jaramillo, F.; Loarca-Pina, M.G. and Reyes, J.L. (2001): Efficacy of $\mathrm{N}$-acetylcysteine to reduce the effects of aflatoxin $\mathrm{B}_{1}$ intoxication in broiler chickens. Poult. Sci. 80:727-734.

Van Egmond, H.P. and Jonker, M.A. (2004): Worldwide regulations on aflatoxins-the situation in 2002. J. Toxicol. Toxin Rev. 23: 273-293.

Wang, J-S.; Busby, W.F.Jr. and Wogan, G.N. (1990): Comparative tissue distribution and 
excretion of orally administered [3H] diacetoxyscirpenol (anguidine) in rats and mice. Toxicol. Appl. Pharmacol. 103:430-40.

Wannop, C.C. (1961): The histopathology of turkey " $\mathrm{X}$ " disease in Great Britain. Avian Dis. 5: 371-381.

Yener, Z.; Celik, I.; Ilhan, F. and Bal, R. (2009): Effects of Urtica dioica $L$. seed on lipid peroxidation, antioxidants and liver pathology in aflatoxin-induced tissue injury in rats. Food and Chemical Toxicology 47: 418-424.

Yildiz, A.O.; Parlat, S.S. and Yildirim, I. (2004): Effect of dietary addition of live yeast (Saccharomyces cerevisiae) on some performance parameters of adult Japanese quail (Coturnix coturnix japonica) induced by aflatoxicosis. Revue Méd. Vét. 155: 38-41.

Yousef, J.M. (2009): The Protective Effects of Selected Mixed Herbal Extracts on Weight, Serum and Liver Tissue in Rats Before and after Exposure to Aflatoxin B1. World J. Med. Sci. 4 (1): 01-08.

Yunus, A.W.; Razzazi-Fazeli, E. and Bohm, J. (2011): Aflatoxin B1 in affecting broiler's performance, immunity, and gastrointestinal tract: a review of history and contemporary Issues. Toxins 3: 566-590.

Zanello, G.; Meurens, F.; Berri, M. and Salmon, $H$. (2009): Saccharomyces boulardii effects on gastrointestinal diseases. Curr. Issues Mol. Biol. 11: 47-58.

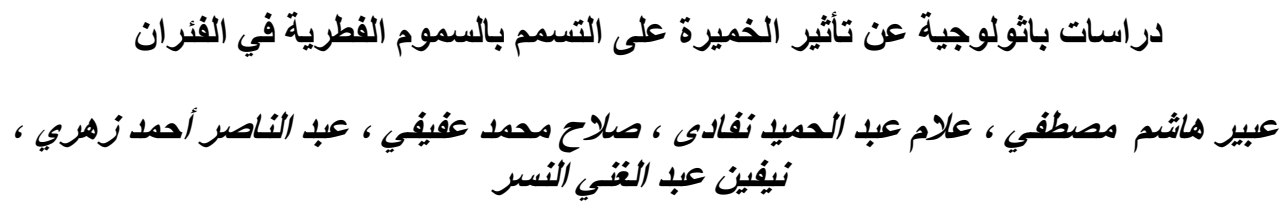

Email: abeerhashim_elhendy@yahoo.com Assiut University web-site: www.aun.edu.eg

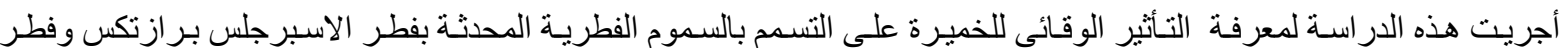

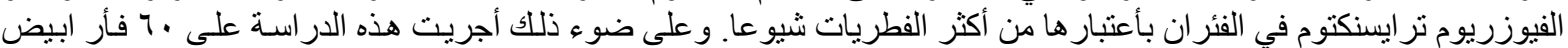

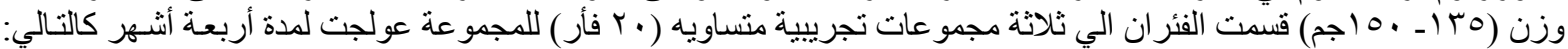

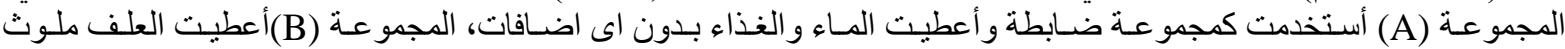

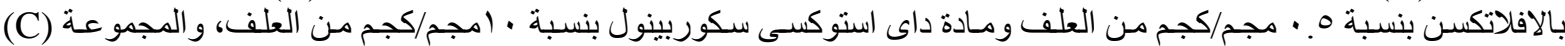

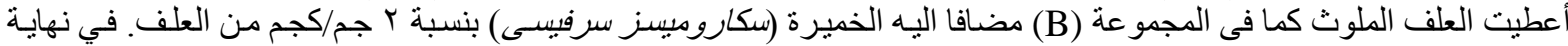

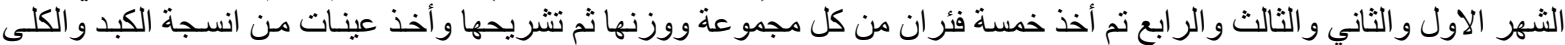

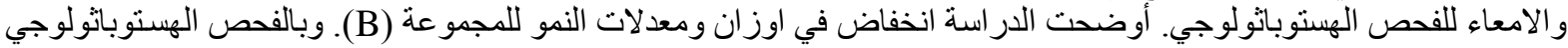

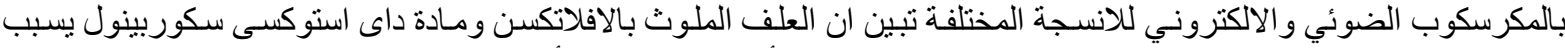

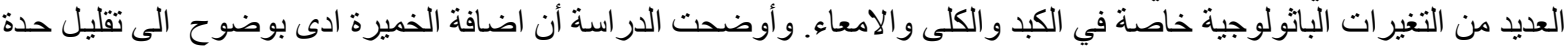

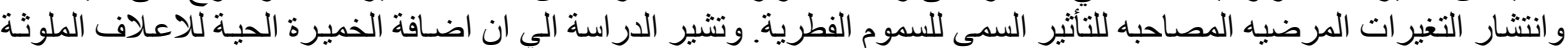
بالسموم الفطرية يحسن من معدلات النمو و القدر ات المناعية للجسم في صورة زئية ولفيرة الخلايا الليمفاوية وخلايا البلازمة. 